\title{
The Urgency of Restorative Justice on Medical Dispute Resolution in Indonesia
}

\author{
Lego Karjoko \\ Faculty of Law, Universitas Sebelas Maret, Surakarta, Indonesia \\ email: legokarjoko@staff.uns.ac.id \\ I Gusti Ayu Ketut Rachmi Handayani \\ Faculty of Law, Universitas Sebelas Maret, Surakarta, Indonesia \\ email: ayu_igk@staff.uns.ac.id \\ Abdul Kadir Jaelani \\ Faculty of Law, Universitas Sebelas Maret, Surakarta, Indonesia \\ email: jaelaniabdulkadir@staff.uns.ac.id \\ Jaco Barkhuizen \\ Department of Criminology and Criminal Justice, University of Limpopo, Limpopo, \\ South Africa \\ email:jaco.barkhuizen@ul.ac.za

\section{Muhammad Jihadul Hayat} \\ Faculty of Sharia and Law, Universitas Islam Negeri Sunan Kalijaga, Yogyakarta, \\ Indonesia \\ email:mjhayat27@gmail.com
}

\begin{abstract}
Article history: Received: November 11, 2021, Accepted: December 21, 2021,
Published: December 31, 2021
\end{abstract}

\begin{abstract}
:
Medical disputes in Indonesia are regulated by a host of laws. The important question that needs to be asked, however, is whether those laws have guaranteed justice for patients and doctors. This study aims to analyze the urgency of restorative justice in medical disputes. It explores secondary data and is normative legal research. The data was gathered through library research consisting of data collection activities based on
\end{abstract}

Author correspondence email: legokarjoko@staff.uns.ac.id Available online at: http:// ejournal.iainmadura.ac.id/index.php/alihkam/ Copyright (c) 2021 by al-ihkam. All Right Reserved 
several publications. This study focuses on legal principles with a doctrinal approach. It concludes that restorative justice is urgent to use in medical, criminal, and civil cases. This is evident in the will of the Health Law which prioritizes mediation as the first mechanism before being brought to trial. Furthermore, the use of restorative justice in medical dispute resolution is driven by the presence of three conditions: First is structural challenges among law enforcers and their limited capabilities in dealing with complex medical cases; Second is the condition of Indonesian correctional institutions which is overburdened and unable to provide maximum output, and the third is the relatively low number of Indonesian health workers.

\title{
Keywords:
}

Medical Disputes; Restorative Justice; and Health Law

\begin{abstract}
Abstrak
Sengketa Medis di Indonesia telah diatur dalam beberapa peraturan perundang-undangan. Namun, pertanyaan penting yang perlu diajukan yaitu apakah peraturan yang ada telah menjamin kedilan bagi pasien dan dokter. Penelitian ini bertujuan untuk menganalisis urgensi prinsip keadilan restoratif dalam penyelesaian sengketa medis. Penelitian ini merupakan penelitian hukum normatif yang mengkaji data sekunder. Pengumpulan data dilakukan dengan studi pustaka (library research), yaitu kegiatan pengumpulan data yang berasal dari berbagai literatur. Penelitian ini fokus pada asas-asas hukum dengan pendekatan dokrinal. Kesimpulan dari penelitian ini adalah bahwa prinsip keadilan restoratif penting diterapkan dalam kasus medis, pidana, maupun perdata. Ini misalnya dapat dilihat dari i'tikad baik dalam Hukum Kesehatan yang mempriorotaskan mediasi sebagai mekanisme pertama sebelum dibawa ke pengadilan. Dalam konteks sengketa medis, prinsip keadilan restoratif menjadi urgen untuk diterapkan sedikitnya karena tiga hal; pertama adalah tantangan struktural di kalangan para penegak hukum serta kemampuan mereka yang terbatas dalam menghadapi kasus medis yang biasanya kompleks. Kedua, kondisi lembaga pemasyarakatan Indonesia yang over kapastias sehingga tidak mampu memberikan output yang maksimal; dan ketiga adalah jumlah tenaga kesehatan di Indonesia yang relatif rendah.
\end{abstract}


Lego Karjoko, I Gusti Ayu Ketut Rachmi Handayani, Abdul Kadir Jaelani, Jaco Barkhuizen, Muhammad Jihadul Hayat

Kata Kunci:

Sengketa Medis; Restorative Justice; Hukum Kesehatan

\section{Introduction}

Doctors are required to work to the best of their abilities, giving their all to each patient. If the results of the doctor's efforts are not the same as what the patient expected, the patient can claim them. ${ }^{1}$ This can result in filing a claim and lawsuit to the police and even filing a civil lawsuit against the doctor because the doctor has committed negligence. ${ }^{2}$

Data from the Indonesian Medical Discipline Honorary Council (MKDKI) show that $80 \%$ of the 135 cases that have been reported are due to poor communication between doctors and patients. This demonstrates that medical disputes start from patients' dissatisfaction because some doctors are considered not completing their work as promised or expected. This makes the patients or their family members look for the cause of the dissatisfaction. It may be due to violations that indicate an unlawful act was committed in the process of performing the medical treatment. This may occur if there is an assumption that the therapeutic contract is not fulfilled or violated by the doctor. ${ }^{3}$

The increasing number of claims and lawsuits filed by the people is usually considered as a failure of treatment performed by doctors, although an increasing number of lawsuits against doctors and hospitals shows that people are starting to realize their rights in

\footnotetext{
${ }^{1}$ M. Flynn, 'Medical Malpractice - Medicolegal Perspectives: Negligence, Standard of Care', in Encyclopedia of Forensic and Legal Medicine: Second Edition, ed. by Jason Payne-James and Roger W B T - Encyclopedia of Forensic and Legal Medicine (Second Edition) Byard (Oxford: Elsevier, 2015), pp. 365-69 <https://doi.org/10.1016/B978-0-12-800034-2.00284-6>.

2 Yuan Li and others, 'A Comparison of Malpractice Lawsuits Mediated and Judged in Court in China', Journal of Forensic and Legal Medicine, 54 (2018), 109-13 <https://doi.org/10.1016/j.jflm.2018.01.002>.

${ }^{3}$ Matías Eduardo Díaz Crescitelli and others, 'Relational Dynamics Involved in Therapeutic Discordance among Prescribers and Patients: A Grounded Theory $\begin{array}{llll}\text { Study', Patient Education } & 2021\end{array}$ <https://doi.org/10.1016/j.pec.2021.05.041>.
} 
the health sector. The claims are commonly based on the negligence of doctors in performing their duties. This can be seen in many cases. ${ }^{4}$

First, the medical case in the Cassation Decision of Supreme Court Number 365 K/Pid/2012, which sentenced dr. Dewa Ayu Sasiary Prawani and two of her friends. Second, the medical dispute case in the Cassation Decision Number 1110 K/Pid.Sus/2012 experienced by dr. Bambang Suprapto. He was charged with practicing medicine without a license and failing to fulfill his obligations to provide medical services in accordance with professional standards and standard operating procedures. Third, the case of dr. Arif Mustika Jufriansya and dr. Rudy Eko Fitranto in the decision of the Central Jakarta District Court Number 1760/Pid.Sus/2016/PN.Jkt.Pst. They were detained by the police officers for negligence and practicing medicine without a permit. Fourth, the medical case of dr. Harun Rosidi in Blitar District Court Decision Number 233/Pid.B/2016/PN.Blt. dr. Harun Rosidi was charged with practicing medicine without a registration certificate. Fifth, Suharto's medical case in the Singkawang District Court Decision Number 16/Pid.Sus/2017/PN.Skw. The verdict stated that defendant Suharto had been legally and convincingly proven guilty of committing a criminal act using tools, methods, or other means of providing services to the public that gave the impression that he was a qualified doctor.

The cases above were resolved through litigation and led to a long legal process through all levels of legal remedies. ${ }^{5}$ This makes it inefficient in addition to the ending in which some accusations were proven while some others were dropped. Meanwhile, not all parties benefited from the process. For this reason, it is essential to conduct a study on the issue of medical dispute resolution and ways for all parties to obtain justice without focusing on bringing each other

\footnotetext{
4 Rajkumar Cheluvappa and Selwyn Selvendran, 'Medical Negligence - Key Cases and Application of Legislation', Annals of Medicine and Surgery, 57 (2020), 205-11 <https://doi.org/10.1016/j.amsu.2020.07.017>.

${ }_{5}^{5}$ Charles M. Balch and others, 'Personal Consequences of Malpractice Lawsuits on American Surgeons', Journal of the American College of Surgeons, 213.5 (2011), 657-67 <https://doi.org/10.1016/j.jamcollsurg.2011.08.005>.
} 
Lego Karjoko, I Gusti Ayu Ketut Rachmi Handayani, Abdul Kadir Jaelani, Jaco Barkhuizen, Muhammad Jihadul Hayat

down. In this case, restorative justice ${ }^{6}$ is the lens through which we should examine this problem.

Restorative justice is a victim-centered response to crime that allows the victim, the offender, their families, and community representatives to address the harm caused by the crime. This concept emphasizes the interests of victims and their families by seeking to recover the damage and losses suffered by victims of criminal acts. Restorative justice is a concept of resolving a particular crime that involves both parties to jointly seek solutions.

Studies on medical disputes resolution in Indonesia have been conducted for a long time. Scholars have discussed medical dispute resolution from a variety of perspectives. For instance, Novianto wrote about the medical dispute resolution model out-of-court. He focuses on the ideal model of medical dispute resolution in Indonesia, which involves the establishment of an alternative dispute resolution body. ${ }^{7}$ Yuniza, on the other hand, conducted research on the direction of health regulation policy during the era of autonomy in Indonesia. Yuniza's research focused on the regional decentralization of health budgeting. ${ }^{8}$ A more pertinent subject for this paper is Mulyadi's work. Mulyadi's research examines the process of resolving medical malpractice cases via litigation and non-litigation. ${ }^{910}$ Apart from the three studies mentioned previously, Herlianto's work discusses the use of penal mediation as a means of resolving medical malpractice cases. ${ }^{11}$ Researches mentioned above are devoted to medical disputes.

6 Ahmad Syaufi, Diana Haiti, and Mursidah, 'Application of Restorative Justice Values in Settling Medical Malpractice Cases', International Journal of Criminology and Sociology, 10.7 (2021), 103-10 <https:/ / doi.org/10.6000/1929-4409.2021.10.14>.

7 Widodo Tresno Novianto, Alternatif Model Penyelesaian Sengketa Medik Di Luar Pengadilan Melalui Lembaga Penyelesaian Sengketa Medik Dalam Pelayanan Kesehatan (Surakarta: Sebelas Maret University Press, 2014).

8 Mailinda Eka Yuniza, 'Arah Kebijakan Pengaturan Bidang Kesehatan Pada Era Otonomi Luas' (Yogyakarta: Universitas Gadjah Mada, 2016).

${ }_{9}$ Mulyadi Deri, 'Penyelesaian Kasus Kelalaian Medik Melalui Litigasi Dan Non Litigasi Di Indonesia' (Padang: Universitas Andalas, 2019).

10 Deri Mulyadi and others, 'Medical Negligence Dispute Settlement in Indonesia', Indian Journal of Forensic Medicine and Toxicology, 14.4 (2020), 4229-33 <https://doi.org/10.37506/ijfmt.v14i4.12304>.

11 S Herlianto, 'Mediasi Penal Sebagai Alternatif Penyelesaian Perkara Malpraktik Kedokteran' (Semarang: Faculty of Law, Diponegoro University, 2015). 
Apart from those described above, there are still many works in Health law, for example, the works of Susila (2020),12 Pakpahan (2021), ${ }^{13}$ and Irfan (2019). ${ }^{14}$

However, none of the works comprehensively establish restorative justice as a basis for resolving medical disputes. Indeed, Herlianto made numerous references to resolving medical disputes through mediation. However, his research is limited to the application of penal mediation in cases of medical malpractice. In the gap of that, this work focuses on examining why restorative justice should be applied in the resolution of medical disputes in Indonesia. This is significant given that previous works did not include restorative justice as a model or principle of medical conflict resolution.

Substantively, medical dispute resolution based on restorative justice is very essential for several reasons. First, the quantity of medical disputes has increased significantly throughout the years. ${ }^{15}$ Second, based on normative juridical perspective, there are inconsistencies in the norms governing the rights of patients to file a claim for alleged violations of professional standards or malpractice in the health sector. ${ }^{16}$ Third, an empirical study of medical cases shows that the settlement procedure is not taken through the Indonesian Medical Discipline Honorary Council (MKDKI). Fourth, the complexity of the medical case is not easily understood by law enforcers, such as investigators (POLRI), public prosecutors, and judges who implement the ius curia novit principle. Medical

\footnotetext{
12 Muh Endriyo Susila, 'Implementing Dispute Resolution Mechanisms for RESOL Ving Medical Malpractice Cases in Indonesia: Problems and Prospects' (Kuala Lumpur: Ahmad Ibrahim Kulliyyah of Law, International Islamic ..., 2020).

13 Kartina Pakpahan, O K Isnainul, and Emir Syarif Fatahillah Pakpahan, 'Mediation As An Alternative For Medical Dispute Resolution Between Doctors And Patients In Approval Of Medical/Medical Actions', South East Asia Journal of Contemporary Business, Economics and Law, 24.3 (2021), 173-86.

14 Mohammad Irfan, 'Mediation as A Choice of Medical Dispute Settlements in Positive Law of Indonesia', Sociological Jurisprudence Journal, 2.2 (2019), 116-21.

15 Garry Shewan, 'A Business Case for Restorative Justice', London: Restorative Justice Council. Http://Www. Restorativejustice. Org. Uk/Resource/The_Business_case_for_restorative_justice_and_policing, 2010, 1-15.

16 B. M. Dickens, 'Patients' Rights', in Encyclopedia of Applied Ethics, ed. by Ruth B T - Encyclopedia of Applied Ethics (Second Edition) Chadwick (San Diego: Academic Press, 2012), pp. 370-79 <https://doi.org/10.1016/B978-0-12-373932-2.00160-5>.
} 
Lego Karjoko, I Gusti Ayu Ketut Rachmi Handayani, Abdul Kadir Jaelani, Jaco Barkhuizen, Muhammad Jihadul Hayat

complexity, for instance, relates to the task of distinguishing the actions of a medical professional whether it falls into the category of malpractice or medical risk - that exists in every medical action with different levels. ${ }^{17}$

\section{Method}

This is normative legal research. The data was gathered through library research which consisted of numerous publications. ${ }^{18}$ The study focuses on legal principles, legal systematics, and legal synchronization related to restorative justice-based medical dispute resolution. It is descriptive and prescriptive analysis research aiming to analyze the medical dispute resolution model based on restorative justice. ${ }^{19}$ This study uses a doctrinal approach, considering that the focus of research on medical dispute resolution is restorative justicebased. The data analysis technique in this study uses the principle of logical deduction, namely, concluding a general problem to concrete issues. The data obtained in this study are derived from literature studies on primary, secondary, and tertiary legal materials and analyzed by deductive logic, taking into account the concept of law as positive norms in the national legislation system. ${ }^{20}$

\section{Discussion and Result}

\section{Medical Dispute Resolution in Indonesia}

The resolution of medical disputes in Indonesia is basically the same as other disputes in general. Medical disputes can be resolved through litigation mechanisms (procedural law and judicial administration) and non-litigation approaches (non-procedural law

\footnotetext{
17 Gagan Grewal and others, 'Does Knowledge of Medical Risk Influence Patient Decision for Same Day Discharge Following Primary Shoulder Arthroplasty: A Randomized Control Trial', Seminars in Arthroplasty JSES, 31.2 (2021), 353-59 <https://doi.org/10.1053/j.sart.2021.02.008>.

18 Lego Karjoko, Zaidah Nur Rosidah, and I Gusti Ayu Ketut Rahmi Handayani, 'Refleksi Paradigma Ilmu Pengetahuan Bagi Pembangunan Hukum Pengadaan Tanah', Bestuur, 7.2 (2020), 1 <https://doi.org/10.20961/bestuur.v7i1.42694>.

19 Zaidah Nur Rosidah, 'Coherence of the Rules of Sharia Against Pancasila', Bestuur, 8.1 (2020), 40 <https://doi.org/10.20961/bestuur.v8i1.42723>.

20 Triwanto Triwanto and Esti Aryani, 'The Urgency of Granting Authority to Assess Corruption Justice Collaborators', Bestuur, $8.1 \quad$ (2020), 60 <https://doi.org/10.20961/bestuur.v8i1.42720>.
} 
and non-court procedures). Medical dispute resolution through litigation can be taken in the form of both criminal cases and civil cases. ${ }^{21}$ The medical dispute resolution through litigation in criminal cases begins with a medical malpractice claim which is then justified as a medical crime by police officers. A medical crime is an act performed by a doctor by using his professional abilities incorrectly and fulfills the criteria of a crime, such as negligence and intentionally. 22

A medical action cannot only be filed to the criminal court, but also to the civil court. Unlike the criminal mechanism case settlement mechanism, the civil mechanism does not involve the police and prosecutor's office. It runs between parties, i.e., the doctor (midwife, nurse, or hospital) and the patient or his/her family. Therefore, the civil litigation mechanism focuses on the legal relationship between doctors and patients. This means that a medical action will be viewed from the point of view of the legal relationship between doctor and patient. ${ }^{23}$

The legal relationship begins when the treatment process occurs. Indirectly, there has been a mutual agreement between the doctor and the patient, as a "transaction" between the two parties in terms of Health called a therapeutic transaction. Transaction means an agreement that gives birth to a reciprocal relationship between two parties regarding a matter. It contains so-called informed consent, namely a statement of accepting or refusing treatment after receiving information from the doctor before giving consent for medical action. This relates to the right to individual autonomy and selfdetermination as the basis of human rights. In addition, this can also

21I.G.A.K. Rachmi Handayani, Lego Karjoko, and Abdul Kadir Jaelani, 'Model Pelaksanaan Putusan Mahkamah Konstitusi Yang Eksekutabilitas Dalam Pengujian Peraturan Perundang-Undangan Di Indonesia', Bestuur, 7.1 (2019), 36-46 <https://jurnal.uns.ac.id/bestuur/article/view/42700>.

22 Ity Shurtz, 'The Impact of Medical Errors on Physician Behavior: Evidence from Malpractice Litigation', Journal of Health Economics, 32.2 (2013), 331-40 <https://doi.org/10.1016/j.jhealeco.2012.11.011>.

23 Siti Rahma Novikasari, Duc Quang Ly, and Kerry Gershaneck, 'Taxing Micro, Small and Medium Enterprises in Yogyakarta: Regulation and Compliance', Bestuur, 9.1 (2021). 
Lego Karjoko, I Gusti Ayu Ketut Rachmi Handayani, Abdul Kadir Jaelani, Jaco Barkhuizen, Muhammad Jihadul Hayat

prevent fraud or coercion, or in other words, the approval of medical action is a doctor's permission for the patient's interests. ${ }^{24}$

In addition to the litigation settlement of cases above, medical dispute resolution can also be performed through a non-litigious mechanism. Among such methods is medical dispute resolution through the Medical Ethics Honorary Council (MKEK), the Indonesian Medical Discipline Honorary Council (MKDKI), the Consumer Dispute Settlement Agency (BPSK), and Alternative Dispute Resolution (ADR). Procedures consist of mediation, consultation, negotiation, and reconciliation.

Nearly all disputes can be resolved with ADR, both civil and criminal disputes. In Indonesia, however, criminal cases tend to be resolved through litigation involving the police and the Attorney General's Office. The ADR tends to accommodate civil cases along with the investigation process. It can also be resolved by nonlitigation, e.g., through penal mediation by utilizing the principle of opportunity in Article 35 letter c of Law of the Republic of Indonesia Number 16/2004 concerning Prosecution of the Republic of Indonesia. ${ }^{25}$

It is theoretically justified that mediation should be able to be performed at the prosecution level as well as at a court hearing with considerations on legal certainty, legal benefits, and legal justice. ${ }^{26}$ The argument is that if penal mediation is performed at the prosecution level, the principle that can be used is the principle of opportunity, i.e., an idea that gives the prosecutor the authority to set aside cases, even though there is sufficient evidence, for the public interest, both

\footnotetext{
${ }^{24}$ Anna Kawalek, 'A Tool for Measuring Therapeutic Jurisprudence Values during Empirical Research', International Journal of Law and Psychiatry, 71 (2020), 101581 <https://doi.org/10.1016/j.ijlp.2020.101581>.

${ }^{25}$ Nur Putri Hidayah, Quincy R Cloet, and David Pradhan, 'The Implementation of Labor Development Principles According to Job Creation Law as a Reason to Protect Wages Rights', BESTUUR, 9.1 (2021), 94-105.

26 Solmaz Khodapanahandeh and Siti Naaishah Hambali, 'Efficiency of Using " Alternative Dispute Resolution " Method in Medical Negligence Claims', AdvancHowever, the phrase 'public interest' needs comprehensive interpretation, including on whether the interests of both parties are included in the category of public interest. The law itself mentioned that "public interest" is the interest of the nation and state and/or the interest of the wider community. The implementation of the principle of opportunity es in Natural and Applied Sciences, 8.October (2014), 1-5.
} 
with and without conditions, as normatively set out in Article 35 letter c of Law of the Republic of Indonesia Number 16/2004 concerning Prosecution of the Republic of Indonesia.

However, the phrase 'public interest' needs comprehensive interpretation, including whether the interests of both parties are included in the category of public interest. ${ }^{27}$ The law itself mentioned that "public interest" defines as the interest of the nation and state and/or the interest of the wider community. The implementation of the principle of opportunity in the article can only be performed by the General Attorney after receiving advice and opinions from state agencies that have relations with the case. Therefore, any form of medical dispute (civil or criminal dispute) can be resolved with ADR, especially mediation. ${ }^{28}$

\section{The Urgency of Restorative Justice in Medical Dispute Resolution}

Dissatisfaction and disappointment with the formal criminal justice system foster a desire to return to old values and traditional justice practices. This leads to the notion of allocating opportunities to each party involved in criminal acts and the community to play an active role in resolving conflicts. ${ }^{29}$ This is the main principle of restorative justice, i.e., prioritizing the active involvement of the parties in resolving the conflicts. Restorative justice is a concept that responds to the development of the criminal justice system by focusing on the involvement of the community and victims who feel excluded from the mechanisms that work in the traditional criminal justice system. ${ }^{30}$ Restorative justice is carried out through a cooperative process that involves all parties (stakeholders) and is an

\footnotetext{
${ }^{27}$ Murji Iswanty and others, 'Maladministration as Doctor Medical Malpractice: A Health Law Perspective in Indonesia', JL Pol'y \& Globalization, 67 (2017), 167.

28 Murji Iswanty and others, 'Maladministration as Doctor Medical Malpractice: A Health Law Perspective in Indonesia', JL Pol'y E Globalization, 67 (2017), 167.

29 Lois Presser and Patricia Van Voorhis, 'Values and Evaluation: Assessing Processes and Outcomes of Restorative Justice Programs', Crime and Delinquency, 48.1 (2002), 162-88 <https:/ / doi.org/10.1177/0011128702048001007>.

30 Daniel W Van Ness and Karen Heetderks Strong, ‘3 - Restorative Justice: Justice That Promotes Healing BT - Restoring Justice (Fifth Edition)', ed. by Daniel W Van Ness and Karen Heetderks B T - Restoring Justice (Fifth Edition) Strong (Boston: Anderson Publishing, Ltd., 2015), pp. 43-60 <https://doi.org/https://doi.org/10.1016/B978-1-4557-3139-8.00003-0>.
} 
Lego Karjoko, I Gusti Ayu Ketut Rachmi Handayani, Abdul Kadir Jaelani, Jaco Barkhuizen, Muhammad Jihadul Hayat

alternative system of criminal justice by prioritizing an integrated approach to perpetrators on the one hand and victims/communities on the other, as a unit to seek and restore good relations in society. ${ }^{31}$

In the traditional concept of punishment, the victim is always silent, always accepting, and does not interfere in the criminal process. Fundamentally, the idea of restorative justice wants to reorganize the roles of victims, so they have an interest in participating in the criminal process. ${ }^{32}$ In several studies on restorative justice, it is highlighted that "empowerment" relates to the parties in criminal cases (victims, perpetrators, and community). Concretely, empowerment in the context of restorative justice is a process of building bridges between perpetrator(s) and victim(s) or community to discuss and actively participate in the resolution of the criminal matter. ${ }^{33}$

The concept of restorative justice aims to integrate the principle of deliberation in the settlement of criminal cases and is more in line with the basic values of the Indonesian state ideology called Pancasila. The concept of restorative justice theory furthermore offers three answers to important issues in the settlement of criminal cases as follows.

Restorative justice aims to integrate the principle of deliberation in the settlement of criminal cases and is more in line with the basic values of the Indonesian state, known as Pancasila. Restorative justice theory offers answers to important issues in the settlement of criminal cases. First, criticism of the criminal justice system that does not provide opportunities, especially for victims (the criminal justice system disempowers individuals). Second, eliminating conflicts, especially among perpetrators, victims, and the community (taking away the conflict from them). Third, the fact that the feeling of powerlessness experienced as the result of a crime must be overcome to achieve reparation. This is in line with the development of the

31 Shih Ya Kuo, Dennis Longmire, and Steven J. Cuvelier, 'An Empirical Assessment of the Process of Restorative Justice', Journal of Criminal Justice, 38.3 (2010), 318-28 <https:// doi.org/10.1016/j.jcrimjus.2010.03.006>.

${ }^{32}$ Yusriando Yusriando, 'Konstruksi Sistem Jaminan Sosial Nasional Bidang Kesehatan', Bestuur, 7.2 (2019), 122 <https:/ / doi.org/10.20961/bestuur.v7i2.41538>.

33 Kerry Clamp, Restorative Justice in Transition, Restorative Justice in Transition (Routledge, 2013) <https:// doi.org/10.4324/9780203715192>. 
theory of Law on Pancasila, which emphasizes the engineering of policies and behavior that must be based on the values of Pancasila. In the development of the Indonesian legal system, one of the most relevant concepts to use is restorative justice. ${ }^{34}$

Included in the Pancasila value is coherence with a religious point of view. This means that restorative justice-based dispute resolution is the same as, for example, the islah-one of the theories of dispute resolution in Islamic law. Islah is rooted in the word صلح which means "good." Its base form, islah (اصلحا), means to repair, refine, and reconcile (dispute settlement). Islah is usually used specifically to end disputes that occur among people. ${ }^{35}$ Besides, it is also understood as the opposite of the word fasad (فسد) which means damage. The concept of islah as a dispute resolution method seeks to restore conditions or justice from the damage. ${ }^{36}$ The word ishlah has several synonyms, among which are tajdĩd (renewal) and taghyir (change), both of which lead to progress and improvement of the situation. ${ }^{37}$ Hasan Sadily defines ishlah as a form of problem-solving between the parties concerned to settle disputes amicably and peacefully. ${ }^{38}$ Whereas in figh, the word ishlah is defined as peace, which is an agreement established to eliminate disputes between humans, both as individuals, and groups. ${ }^{39}$

In Islamic law, islah is mostly performed when a dispute occurs in the household between husband and wife, for example, in the case of nusyuz (disobedience of a wife) ${ }^{40}$ which causes syiqaq (continuous bickering). However, in some cases, it also occurs during conflicts or

34 Syaufi, Haiti, and Mursidah.

35 Al-Rãghib al-Ashfahani, 'Al-Mufradãt Fĩ Gharĩb Al-Quree An' (Beirut: Beirut: Dar al-Ma'rifah), p. 284.

36 Ibn Manzūr, 'Lisãn Al-'arab, Vol. 3-4' (Mesir: al-Dãr al-Mishriyyah Lita'lĩf wa al-Tarjamah), p. 348.

37 Ibn Manzūr, 'Lisãn Al-'arab, Vol. 3-4' (Mesir: al-Dãr al-Mishriyyah Litaelĩf wa al-Tarjamah), p. 348.

38 Hassan Shadily, Ensiklopedi Indonesia (Jakarta: Ichtiar Baru-Van Hoeve, 1980).

39 Abu Muhammad Mahmud Ibn Al-Aynayni, 'Ahmad. Al-Bidãyah Fi Syarh AlHidãyah Vol-9' (Beirut: Dar al-Fikr), p. 3.

40 Ibn Kathir, 'Tafsir Al-Quran Al Adhim Vol 2' (Beiru: Dar El-Fikr, 1999), p. 296. 
Lego Karjoko, I Gusti Ayu Ketut Rachmi Handayani, Abdul Kadir Jaelani, Jaco Barkhuizen, Muhammad Jihadul Hayat

wars, for example, during Siffin and Jamal war. ${ }^{41}$ Its regard for restorative justice is apparent. Islah is a method of dispute resolution in Islam that is based on peace. Peace itself is oriented for recovery and any effort to build it must be conducted fairly. In the normative view, this islah goes hand in hand with justice as confirmed in alHujurat verse 9. Therefore, it can be said that Islam is in harmony with restorative justice. Theoretically, restorative justice-based medical dispute resolution is the same as islah-based medical dispute resolution because both emphasize peace and fair restoration of the situation.

Practically, restorative justice is a process that involves all parties in a crime to find a way to recover from the impact of the crime while choosing a mechanism to overcome it. This concept already resembles the practice of penal mediation carried out at various practical levels. ${ }^{42}$ To get a simpler explanation, the following table enlists the difference between restorative justice and retributive justice. ${ }^{43}$

Table 1

Differences between the Principles of Retributive Justice and Restorative Justice

\begin{tabular}{|l|l|l|}
\hline No & Retributive Justice & Restorative Justice \\
\hline 1 & $\begin{array}{l}\text { Crime is defined as a violation } \\
\text { of the (law) of the state }\end{array}$ & $\begin{array}{l}\text { Crime is defined as a violation } \\
\text { among individuals }\end{array}$ \\
\hline 2 & $\begin{array}{l}\text { The position of the parties is } \\
\text { contradictory and emphasizes } \\
\text { the legal process }\end{array}$ & $\begin{array}{l}\text { The position of the parties is to } \\
\text { engage in dialogue and emphasize } \\
\text { the negotiation process }\end{array}$ \\
\hline 3 & Making use of suffering for & Restitution as a means of \\
\hline
\end{tabular}

${ }^{41}$ Abu Abdullah Muhammad bin Al-Qurtubi and Ahmad bin Abu Bakr Al-Ansari, 'Al-Jami'li Ahkam Al-Qur'an' (Beirut: Muassasah al-Risalah, 2003), 323.

42 Daniel W. Van Ness and Karen Heetderks Strong, '2 - A Brief History of Restorative Justice: The Development of a New Pattern of Thinking', in Restoring Justice, ed. by Daniel W Van Ness and Karen Heetderks B T - Restoring Justice (Fifth Edition) Strong (Boston: Anderson Publishing, Ltd., 2015), pp. 23-41 <https://doi.org/https://doi.org/10.1016/B978-1-4557-3139-8.00002-9>.

43 Michele R. Decker and others, 'Defining Justice: Restorative and Retributive Justice Goals Among Intimate Partner Violence Survivors', Journal of Interpersonal Violence, 2020, 0886260520943728 <https://doi.org/10.1177/0886260520943728>. 


\begin{tabular}{|c|c|c|}
\hline & sentencing and prevention & $\begin{array}{l}\text { improving both parties; the goal is } \\
\text { to make reconciliation/recovery }\end{array}$ \\
\hline 4 & $\begin{array}{l}\text { Justice is defined rigidly } \\
\text { according to law }\end{array}$ & $\begin{array}{l}\text { Justice is defined according to the } \\
\text { rights that arise because of the } \\
\text { relationship with other parties }\end{array}$ \\
\hline 5 & $\begin{array}{l}\text { Crime is seen as a conflict } \\
\text { between the individual and } \\
\text { the state }\end{array}$ & $\begin{array}{l}\text { Crime is seen as a conflict among } \\
\text { individuals }\end{array}$ \\
\hline 6 & $\begin{array}{l}\text { The suffering of the } \\
\text { community member (victim) is } \\
\text { replaced with the suffering of } \\
\text { other members of the } \\
\text { community (the perpetrator). }\end{array}$ & $\begin{array}{l}\text { Reconciliation or recovery of } \\
\text { damage/suffering of the } \\
\text { community }\end{array}$ \\
\hline 7 & $\begin{array}{l}\text { The community is not actively } \\
\text { involved in the legal process } \\
\text { because it is already } \\
\text { represented by the state. }\end{array}$ & $\begin{array}{l}\text { The community serves as the } \\
\text { facilitator in the recovery process }\end{array}$ \\
\hline 8 & $\begin{array}{l}\text { Encouraging (spirit of) } \\
\text { competition }\end{array}$ & $\begin{array}{l}\text { Encouraging the spirit of } \\
\text { belongingness by prioritizing the } \\
\text { values of mutual help }\end{array}$ \\
\hline 9 & $\begin{array}{l}\text { Conflict resolution is } \\
\text { performed by the state to the } \\
\text { perpetrators (the victim is } \\
\text { neglected, and the perpetrator } \\
\text { is passive) }\end{array}$ & $\begin{array}{l}\text { Aiming at solving problems; the } \\
\text { roles of the victim and the } \\
\text { perpetrator are both recognized } \\
\text { (victim's rights/interests are } \\
\text { recognized and the perpetrator is } \\
\text { encouraged to take responsibility to } \\
\text { fulfill it) }\end{array}$ \\
\hline 10 & $\begin{array}{l}\text { The perpetrator's } \\
\text { accountability is realized by } \\
\text { punishment }\end{array}$ & $\begin{array}{l}\text { The perpetrator's responsibility is } \\
\text { given the understanding as to the } \\
\text { realized consequences } \\
\text { of his/her fault and the perpetrator } \\
\text { is helped to decide how things may } \\
\text { go back as it is }\end{array}$ \\
\hline 11 & $\begin{array}{l}\text { Misconduct is only limited by } \\
\text { law regardless of the moral, } \\
\text { social, economic, or political } \\
\text { dimensions }\end{array}$ & $\begin{array}{l}\text { Misconduct is misunderstood in its } \\
\text { entirety of context, fine } \\
\text { morals, economics, and politics }\end{array}$ \\
\hline 12 & $\begin{array}{l}\text { The perpetrator's } \\
\text { accountability is given to the } \\
\text { state and society abstractly }\end{array}$ & $\begin{array}{l}\text { The perpetrator's responsibility } \\
\text { aims at the victim }\end{array}$ \\
\hline
\end{tabular}


Lego Karjoko, I Gusti Ayu Ketut Rachmi Handayani, Abdul Kadir Jaelani, Jaco Barkhuizen, Muhammad Jihadul Hayat

\begin{tabular}{|l|l|l|}
\hline 13 & $\begin{array}{l}\text { Reaction to conflict is focused } \\
\text { on the perpetrator's past } \\
\text { actions }\end{array}$ & $\begin{array}{l}\text { Reaction to conflict is focused on } \\
\text { the suffering caused by the } \\
\text { perpetrator's actions }\end{array}$ \\
\hline 14 & $\begin{array}{l}\text { The stigma of crime cannot be } \\
\text { removed }\end{array}$ & $\begin{array}{l}\text { The stigma of crime can be } \\
\text { removed through remedial action }\end{array}$ \\
\hline 15 & $\begin{array}{l}\text { There is no encouragement } \\
\text { (against the perpetrator) to } \\
\text { regret his/her actions and } \\
\text { (towards the victim) to forgive } \\
\text { the perpetrator }\end{array}$ & $\begin{array}{l}\text { Making the emergence of the } \\
\text { perpetrator's remorse and } \\
\text { forgiveness from the victim } \\
\text { possible }\end{array}$ \\
\hline 16 & $\begin{array}{l}\text { Conflict resolution is only } \\
\text { carried out by law } \\
\text { enforcement officers. }\end{array}$ & $\begin{array}{l}\text { Conflict resolution is performed by } \\
\text { involving the parties (victim, } \\
\text { perpetrator, and community) }\end{array}$ \\
\hline
\end{tabular}

\section{Reasons for Mainstreaming Restorative Justice on Medical Dispute Resolution}

Legal regulations in the health sector have anticipated if a dispute occurs in the health sector. In Law of the Republic of Indonesia Number 29/2004 concerning Medical Practice jis, Law of the Republic of Indonesia Number 36/2014 concerning Health Workers, and Law of the Republic of Indonesia Number 36/2009 concerning Health contain the basics of sentencing if there is a deviation (dollus) in medical action. These actions can be categorized as medical crimes if they meet the criminal elements stated in the criminal article in the law. ${ }^{44}$ The articles above can be briefly seen in the following table.

44 Wulandari Berliani Putri and others, 'Medicolegal Perspective on PhysicianInduced Demand Issue', BESTUUR, 9.1 (2021), 106-24. 
Table 2

Categories of Medical Measures in Health-related Laws

\begin{tabular}{|c|c|c|}
\hline No & $\begin{array}{l}\text { Types of Penalized } \\
\text { Medical Actions }\end{array}$ & Article Terms \\
\hline 1 & $\begin{array}{l}\text { Practicing medicine without } \\
\text { having a Registration } \\
\text { Certificate (STR) }\end{array}$ & $\begin{array}{l}\text { Law of the Republic of } \\
\text { Indonesia Number 29/2004 } \\
\text { Article } 75 \text { (1), (2), (3) jo Law of } \\
\text { the Republic of Indonesia } \\
\text { Number 36/2014 Article } 85 \text { (1) } \\
\text { (2) }\end{array}$ \\
\hline \multirow{2}{*}{2} & \multirow{2}{*}{$\begin{array}{l}\text { Medical practice without } \\
\text { having a Practice License (SIP) }\end{array}$} & $\begin{array}{l}\text { Law of the Republic of } \\
\text { Indonesia Number 29/2004 } \\
\text { Article } 76\end{array}$ \\
\hline & & $\begin{array}{l}\text { jo Law of the Republic of } \\
\text { Indonesia Number } 36 / 2014 \\
\text { Article } 80 \text {, Article } 86(1),(2)\end{array}$ \\
\hline 3 & $\begin{array}{l}\text { Deliberately giving the } \\
\text { impression as if a doctor who } \\
\text { has a Registration Certificate } \\
\text { (STR) and Practice License } \\
\text { (SIP) }\end{array}$ & $\begin{array}{l}\text { Law of the Republic of } \\
\text { Indonesia Number } 29 / 2004 \\
\text { Article } 77 \text { and Article } 78\end{array}$ \\
\hline 4 & $\begin{array}{l}\text { Deliberately not putting up a } \\
\text { nameplate, not making } \\
\text { medical records, and not } \\
\text { fulfilling obligations set out by } \\
\text { law }\end{array}$ & $\begin{array}{l}\text { Law of the Republic of } \\
\text { Indonesia Number } 29 / 2004 \\
\text { Article } 79\end{array}$ \\
\hline 5 & $\begin{array}{l}\text { Hiring doctors who do not } \\
\text { have a Practice License (SIP) }\end{array}$ & $\begin{array}{l}\text { Law of the Republic of } \\
\text { Indonesia Number } 29 / 2004 \\
\text { Article } 80\end{array}$ \\
\hline 6 & $\begin{array}{l}\text { Deliberately not providing } \\
\text { first aid to patients in an } \\
\text { emergency situation }\end{array}$ & $\begin{array}{l}\text { Law of the Republic of } \\
\text { Indonesia Number 36/2009 } \\
\text { concerning Health, Article } 190 \\
\text { (1), (2) }\end{array}$ \\
\hline 7 & $\begin{array}{l}\text { Opening traditional health } \\
\text { service using tools and } \\
\text { technology without a permit } \\
\text { that results in property loss, } \\
\text { serious injury or death }\end{array}$ & $\begin{array}{l}\text { Law of the Republic of } \\
\text { Indonesia Number 36/2009 } \\
\text { concerning Health, Article } 191\end{array}$ \\
\hline
\end{tabular}


Lego Karjoko, I Gusti Ayu Ketut Rachmi Handayani, Abdul Kadir Jaelani, Jaco Barkhuizen, Muhammad Jihadul Hayat

\begin{tabular}{|r|l|l|}
8 & $\begin{array}{l}\text { Trading one's organs or body } \\
\text { tissues }\end{array}$ & $\begin{array}{l}\text { Law of the Republic of } \\
\text { Indonesia Number 36/2009 } \\
\text { concerning Health, Article 192 }\end{array}$ \\
\hline 9 & $\begin{array}{l}\text { Making plastic and } \\
\text { reconstructive surgery for the } \\
\text { purpose of changing one's } \\
\text { identity }\end{array}$ & $\begin{array}{l}\text { Law of the Republic of } \\
\text { Indonesia Number 36/2009 } \\
\text { concerning Health, Article 193 }\end{array}$ \\
\hline 10 & Performing abortion & $\begin{array}{l}\text { Law of the Republic of } \\
\text { Indonesia Number 36/2009 } \\
\text { concerning Health, Article 194 }\end{array}$ \\
\hline 11 & $\begin{array}{l}\text { Trading blood } \\
\text { Law of the Republic of } \\
\text { Indonesia Number 36/2009 } \\
\text { concerning Health, Article 195 }\end{array}$ \\
\hline 12 & $\begin{array}{l}\text { Producing or distributing } \\
\text { medical devices that do not } \\
\text { meet the standards and/or } \\
\text { requirements for safety, } \\
\text { efficacy or benefit, and quality }\end{array}$ & $\begin{array}{l}\text { Law of the Republic of } \\
\text { Indonesia Number 36/2009 } \\
\text { concerning Health, Article 196 }\end{array}$ \\
\hline 13 & $\begin{array}{l}\text { Producing or distributing } \\
\text { pharmaceutical stocks and/or } \\
\text { medical devices that do not } \\
\text { have a distribution permit }\end{array}$ & $\begin{array}{l}\text { Law of the Republic of } \\
\text { Indonesia Number 36/2009 } \\
\text { concerning Health, Article 197 }\end{array}$ \\
\hline $\begin{array}{l}\text { Interfering the exclusive } \\
\text { breastfeeding program }\end{array}$ & $\begin{array}{l}\text { Law of the Republic of } \\
\text { Indonesia Number 36/2009 } \\
\text { concerning Health, Article 200 }\end{array}$ \\
\hline
\end{tabular}

The priority of restorative justice in medical disputes is based on three reasons, including:

First is an unprepared structure of the criminal justice system in Indonesia in handling medical cases. The structural problems of the criminal justice system towards mechanism of medical dispute resolution in Indonesia include the paradigmatic problem of law enforcement officers as they generally dwell on the principle of positivism. Besides, it is also about their capacity and capability in handling medical criminal cases as well as their orientation that has not mainstreamed alternative approaches, i.e., restorative justice. 
The apparatus referred to in this case include sub-systems with their respective scopes in the criminal justice process, such as police officers, prosecutors, courts, correctional institutions, and advocates. From a positivist perspective, the focus of attention of these officers tends to be towards enforcing regulations, structures, and procedures that are typically not human-oriented for both victims and perpetrators. 45 This is a part of the characteristic of paradigmatic change from the order of justice to the order of laws and procedures with legal rationalization, structure, formulation, and bureaucratization. The focus of attention shifts from people or humanity towards an emphasis on rules, structures, and procedures. ${ }^{46}$ Therefore, the concept of this application is only normative in the orientation. Alternative approaches, such as strengthening mediation based on restorative justice or alternative non-litigation dispute resolution become secondary mechanisms. In fact, officers, especially investigators, have difficulties in resolving medical cases because the process of investigating medical crimes requires special abilities in the field of medical and law science altogether. It is fair to say, therefore, that this type of dispute needs a special court such as a special court for terrorism, corruption, or cases engaging children.

Second is the problem of correctional institutions. It is well known that Indonesia's Correctional Institutions (known as Lembaga Pemasyarakatan/Lapas) are facing a capacity crisis. The higher population growth is accompanied by the complexity of life and the opening of various new modes of crime which have boosted the increase in the number of criminal acts in many sectors. In the end, this has an impact on the increase in the number of residents of Lapas. Conceptually, the Lapas is a place or facility for fostering prisoners, but it seems less efficient because of the number of prisoners. This problem may occur in all prisons in Indonesia.

45 Brian Z. Tamanaha, 'Legal Positivism', in International Encyclopedia of the Social $\mathcal{E}$ Behavioral Sciences: Second Edition, ed. by James D B T - International Encyclopedia of the Social \& Behavioral Sciences (Second Edition) Wright (Oxford: Elsevier, 2015), pp. 762-66 <https://doi.org/10.1016/B978-0-08-097086-8.86074-2>.

46 Satjipto Rahardjo, Hukum Dan Perubahan Sosial Suatu Tinjauan Teoritis Serta Pengalaman-Pengalaman Di Indonesia, Yogyakarta: Genta Publishing (Genta Publishing, 2009). 
Lego Karjoko, I Gusti Ayu Ketut Rachmi Handayani, Abdul Kadir Jaelani, Jaco Barkhuizen, Muhammad Jihadul Hayat

Currently, both detention centers and prisons throughout Indonesia are facing overcapacity. The Director General of Corrections revealed that the problem of overcapacity in detention centers and prisons is a common phenomenon in Indonesia. The capacity of prisons throughout Indonesia consists of no more than 136,000 people, but the Rutan and Lapas are currently inhabited by more than 272,000 people. This means that the prison's situation is two-fold of its standard capacity. The development of the prison situation as of July 2021 is listed in the following table.

Table 3

Total Capacity of Detainees and Convicts 2021

\begin{tabular}{|c|c|c|c|c|}
\hline No & Regional Office & $\begin{array}{c}\text { Detainees } \\
\text { and } \\
\text { Convicts }\end{array}$ & Capacity & $\begin{array}{c}\% \\
\text { Overcapacity }\end{array}$ \\
\hline 1 & Aceh & 9,366 & 4,105 & 128 \\
\hline 2 & Bali & 3,701 & 1,518 & 144 \\
\hline 3 & Bangka Belitung & 2,523 & 1,311 & 92 \\
\hline 4 & Banten & 10,694 & 5,197 & 106 \\
\hline 5 & Bengkulu & 2,689 & 1,742 & 54 \\
\hline 6 & Yogyakarta & 1,787 & 2,039 & 0 \\
\hline 7 & Jakarta & 18,140 & 5,791 & 213 \\
\hline 8 & Gorontalo & 1,009 & 1,078 & 0 \\
\hline 9 & Jambi & 4,958 & 2,391 & 107 \\
\hline 10 & West Java & 23,030 & 16,761 & 37 \\
\hline 11 & Central Java & 13,961 & 9,459 & 48 \\
\hline 12 & East Java & 28,662 & 13,246 & 116 \\
\hline 13 & West Kalimantan & 5,983 & 2,579 & 132 \\
\hline 14 & South Kalimantan & 9,990 & 3,657 & 173 \\
\hline 15 & Central Kalimantan & 4,545 & 2,271 & 100 \\
\hline 16 & East Kalimantan & 12,712 & 3,586 & 254 \\
\hline 17 & Kepulauan Riau & 4,830 & 2,733 & 77 \\
\hline 18 & Lampung & 9,051 & 5,348 & 69 \\
\hline 19 & Maluku & 1,671 & 1,409 & 19 \\
\hline 20 & North Maluku & 1,221 & 1,417 & 0 \\
\hline 21 & West Nusa Tenggara & 3,430 & 1,929 & 78 \\
\hline
\end{tabular}




\begin{tabular}{|r|l|r|r|r|}
22 & East Nusa Tenggara & 3,076 & 2,903 & 6 \\
\hline 23 & Papua & 2,630 & 2,267 & 16 \\
\hline 24 & West Papua & 1,121 & 980 & 14 \\
\hline 25 & Riau & 14,122 & 4,455 & 217 \\
\hline 26 & West Sulawesi & 1,209 & 1,022 & 18 \\
\hline 27 & South Sulawesi & 10,929 & 6,109 & 79 \\
\hline 28 & Central Sulawesi & 3,730 & 1,711 & 118 \\
\hline 29 & Southeast Sulawesi & 2,923 & 2,146 & 36 \\
\hline 30 & North Sulawesi & 2,482 & 2,145 & 16 \\
\hline 31 & West Sumatra & 6,352 & 3,217 & 97 \\
\hline 32 & South Sumatra & 15,162 & 6,605 & 130 \\
\hline 33 & North Sumatra & 34,988 & 12,854 & 172 \\
\hline & Total & 272,677 & 135,981 & 101 \\
\hline
\end{tabular}

Source: http://smslap.ditjenpas.go.id/public/grl/current/monthly data updated Juli 2021

Based on the table above, putting the paradigm of retributive justice is the same as adding to the congestion of the number above. This means that based on the infrastructure of the Correctional Institution, the choice of litigation path with the aim of punishing criminal offenders is not the main choice in solving the problems. ${ }^{47}$ Herein lies the urgency of restorative justice on dispute resolution mechanism as the most reasonable approach in dealing with medical disputes.

Civil litigation can also actually be taken as a choice because it has a legal basis for implementing integrated mediation in courts that is more applicable, unlike criminal litigation. For example, there is Supreme Court Regulation Number 1/2008 which was amended by Supreme Court Regulation Number 1/2016 concerning Mediation in Courts as well as Law of the Republic of Indonesia Number 30/1999 as the main basis for non-litigation Alternative Dispute Resolution. The considerations above are physical ones instead of managerial

\footnotetext{
47 Saidah Fasihah Binti Che Yussoff and Rohaida Nordin, 'Freedom of Expression in Malaysia: Compatibility with the International Human Rights Standard Saidah', Bestuur, 9.1 (2021), 44-59.
} 
Lego Karjoko, I Gusti Ayu Ketut Rachmi Handayani, Abdul Kadir Jaelani, Jaco Barkhuizen, Muhammad Jihadul Hayat

considerations and do not include the conditions of other supporting facilities. 48

The third is the condition of medical personnel in Indonesia. A health worker is every person who devotes himself to the health sector and has the knowledge and/or skills through education in the health sector which for certain types, requires the authority to do health efforts. ${ }^{49}$ The law classifies health workers into several clumps and sub-clusters, i.e., medical personnel, clinical psychology staff, nursing staff, midwifery personnel, pharmaceutical workers, public health workers, environmental health workers, nutritionists, physical therapy personnel, medical technicians, biomedicine technical personnel, traditional health workers, and other health workers. In terms of quantity, the number of health workers in Indonesia is listed in the following table.

Table 4

Number of Doctors in Indonesia 2021

\begin{tabular}{|c|l|r|}
\hline No & \multicolumn{1}{|c|}{ Province } & $\begin{array}{c}\text { Number of } \\
\text { Doctor }\end{array}$ \\
\hline 1 & Aceh & 3114 \\
\hline 2 & North Sumatra & 6464 \\
\hline 3 & West Sumatra & 3116 \\
\hline 4 & Riau & 3120 \\
\hline 5 & Jambi & 1769 \\
\hline 6 & South Sumatra & 2857 \\
\hline 7 & Bengkulu & 927 \\
\hline 8 & Lampung & 2595 \\
\hline 9 & Kepulauan Bangka Belitung & 855 \\
\hline 10 & Kepulauan Riau & 1376 \\
\hline 11 & Jakarta & 17032 \\
\hline 12 & West Java & 16705 \\
\hline
\end{tabular}

48 Loresta Cahyaning Lintang, Adriano Martufi, and J W Ouwerker, 'The Alternative Concepts of Blasphemy Law in Indonesia: Legal Comparison with Ireland and Canada', BESTUUR, 9.1 (2021), 17-33.

49 Teguh Dartanto and others, 'Enrolment of Informal Sector Workers in the National Health Insurance System in Indonesia: A Qualitative Study', Heliyon, 6.11 (2020), e05316 <https://doi.org/10.1016/j.heliyon.2020.e05316>. 


\begin{tabular}{|r|l|r|}
\hline No & \multicolumn{1}{|c|}{ Province } & $\begin{array}{r}\text { Number of } \\
\text { Doctor }\end{array}$ \\
\hline 13 & Central Java & 13625 \\
\hline 14 & Yogyakarta & 3648 \\
\hline 15 & East Java & 15239 \\
\hline 16 & Banten & 5037 \\
\hline 17 & Bali & 4225 \\
\hline 18 & West Nusa Tenggara & 1575 \\
\hline 19 & East Nusa Tenggara & 1234 \\
\hline 20 & West Kalimantan & 1407 \\
\hline 21 & Central Kalimantan & 1101 \\
\hline 22 & South Kalimantan & 1799 \\
\hline 23 & East Kalimantan & 2233 \\
\hline 24 & North Kalimantan & 482 \\
\hline 25 & North Sulawesi & 2203 \\
\hline 26 & Central Sulawesi & 1153 \\
\hline 27 & South Sulawesi & 4050 \\
\hline 28 & Southeast Sulawesi & 1053 \\
\hline 29 & Gorontalo & 555 \\
\hline 30 & West Sulawesi & 481 \\
\hline 31 & Maluku & 724 \\
\hline 32 & North Maluku & 494 \\
\hline 33 & West Papua & 475 \\
\hline 34 & Papua & 968 \\
\hline & & Total \\
\hline
\end{tabular}

Source: http://bppsdmk.kemkes.go.id/info_sdmk/info/index?rumpun=101

Meanwhile, the ratio of doctors, including general practitioners and dentists, and patients is as follow: 
Lego Karjoko, I Gusti Ayu Ketut Rachmi Handayani, Abdul Kadir Jaelani, Jaco Barkhuizen, Muhammad Jihadul Hayat

Table 5

Ratio of General Practitioners and Dentists

(1:100,000 population)

\begin{tabular}{|c|c|c|c|c|}
\hline No & Region & Population & $\begin{array}{c}\text { Ratio of } \\
\text { General } \\
\text { Practitioners }\end{array}$ & $\begin{array}{l}\text { Ratio of } \\
\text { Dentists }\end{array}$ \\
\hline 1 & Aceh & 5281314 & $1: 30$ & 1:06 \\
\hline 2 & North Sumatra & 14415391 & $1: 23$ & $1: 06$ \\
\hline 3 & West Sumatra & 5382077 & $1: 20$ & 1:08 \\
\hline 4 & Riau & 6814909 & $1: 24$ & 1:07 \\
\hline 5 & Jambi & 3570272 & $1: 28$ & 1:07 \\
\hline 6 & South Sumatra & 8370320 & $1: 15$ & 1:03 \\
\hline 7 & Bengkulu & 1963300 & $1: 23$ & 1:06 \\
\hline 8 & Lampung & 8370485 & $1: 21$ & 1:04 \\
\hline 9 & $\begin{array}{l}\text { Kepulauan Bangka } \\
\text { Belitung }\end{array}$ & 1459873 & $1: 269$ & $1: 51$ \\
\hline 10 & Kepulauan Riau & 2136521 & $1: 26$ & 1:06 \\
\hline 11 & Jakarta & 10467629 & $1: 65$ & $1: 19$ \\
\hline 12 & West Java & 48683861 & $1: 11$ & 1:03 \\
\hline 13 & Central Java & 34490835 & $1: 17$ & 1:04 \\
\hline 14 & Yogyakarta & 3802872 & $1: 54$ & $1: 19$ \\
\hline 15 & East Java & 39500851 & $1: 22$ & 1:06 \\
\hline 16 & Banten & 12689736 & $1: 11$ & $1: 04$ \\
\hline 17 & Bali & 4292154 & $1: 36$ & $1: 10$ \\
\hline 18 & West Nusa Tenggara & 5013687 & $1: 27$ & 1:05 \\
\hline 19 & East Nusa Tenggara & 5371519 & $1: 14$ & $1: 03$ \\
\hline 20 & West Kalimantan & 5001664 & $1: 17$ & $1: 03$ \\
\hline 21 & Central Kalimantan & 2660209 & $1: 19$ & 1:04 \\
\hline 22 & South Kalimantan & 4182695 & $1: 21$ & 1:06 \\
\hline 23 & East Kalimantan & 3648835 & $1: 30$ & 1:08 \\
\hline 24 & North Kalimantan & 716407 & $1: 35$ & 1:07 \\
\hline 25 & North Sulawesi & 2484392 & $1: 37$ & 1:04 \\
\hline 26 & Central Sulawesi & 3010443 & $1: 18$ & 1:04 \\
\hline 27 & South Sulawesi & 8771970 & $1: 19$ & 1:09 \\
\hline
\end{tabular}




\begin{tabular}{|c|l|r|r|r|}
\hline No & \multicolumn{1}{|c|}{ Region } & Population & $\begin{array}{c}\text { Ratio of } \\
\text { General } \\
\text { Practitioners }\end{array}$ & $\begin{array}{c}\text { Ratio of } \\
\text { Dentists }\end{array}$ \\
\hline 28 & Southeast Sulawesi & 2653654 & $1: 17$ & $1: 06$ \\
\hline 29 & Gorontalo & 1185492 & $1: 27$ & $1: 05$ \\
\hline 30 & West Sulawesi & 1355554 & $1: 12$ & $1: 04$ \\
\hline 31 & Maluku & 1773776 & $1: 14$ & $1: 02$ \\
\hline 32 & North Maluku & 1232632 & $1: 20$ & $1: 03$ \\
\hline 33 & West Papua & 937458 & $1: 26$ & $1: 04$ \\
\hline 34 & Papua & 3322526 & $1: 23$ & $1: 03$ \\
\hline
\end{tabular}

Source: http://bppsdmk.kemkes.go.id/info_sdmk/info/renbut

Based on the data above, it can be observed that the ratio of the population and the availability of health personnel (practitioners and dentists) is uneven and has a wide gap. For example, Aceh has 30 general practitioners and 6 dentists per 100,000 people. In the DKI Jakarta area, there are 65 general practitioners per 100,000 population and 19 dentists per 100,000 population. In West Sulawesi, there are 12 general practitioners and 3 dentists per 100,000 population. These data are sufficient to illustrate that the quantity of medical personnel in Indonesia is still lacking. ${ }^{50}$ Therefore, it is common that public perception of health problems is still poor. Furthermore, based on data from the World Bank, the number of doctors in Indonesia is the second-lowest after Cambodia, i.e., 0.4 doctors per 1,000 people. This means that Indonesia only has 4 doctors serving 10,000 people. This number is much lower than that of Singapore which has two doctors per 1,000 people. ${ }^{51}$

These Indonesia' s statistical data show the availability of doctors' resources amidst Indonesian society. In simple terms, the communities need for medical personnel is still not being fulfilled. Such a situation also represents the underdevelopment of medical resources in Indonesia compared to other Southeast Asian countries,

50 Agung Dwi Laksono, Ilham Akhsanu Ridlo, and Ernawaty Ernawaty, 'Distribution Analysis of Doctors in Indonesia', Jurnal Administrasi Kesehatan Indonesia, 8.1 (2020), 29 <https://doi.org/10.20473/jaki.v8i1.2020.29-39>.

51 Agung Dwi Laksono, Ilham Akhsanu Ridlo, and Ernawaty Ernawaty, 'Distribution Analysis of Doctors in Indonesia', Jurnal Administrasi Kesehatan Indonesia, 8.1 (2020), 29 <https:// doi.org/10.20473/jaki.v8i1.2020.29-39>. 
Lego Karjoko, I Gusti Ayu Ketut Rachmi Handayani, Abdul Kadir Jaelani, Jaco Barkhuizen, Muhammad Jihadul Hayat

except Cambodia. In addition to numerical and legal data as mentioned above, there are social phenomena that adequately illustrate that the condition of Indonesian medical personnel still needs further attention. 52

For instance, there had been a massive demonstration by doctors accompanied by a strike in November 2013. It is the aftermath of a medical dispute that befell dr. Dewa Ayu Sasiary and her two colleagues. Many doctors in various regions united to criticize the cassation decision which stated that dr. Ayu and her two colleagues are guilty. As a result, patients who need their medical services at that time were cared less than optimal. For example, a patient from Ciamis-West Java had to cancel the scheduled operation of an appendectomy at a hospital because the doctor took part in the solidarity action. ${ }^{53}$ It means that mechanism for criminal litigationbased medical dispute resolution is a serious problem among doctors in Indonesia. As a result, it is not only the doctors who feel worried but the patients, who at the same time, may indirectly become victims. These conditions reinforce that in terms of resolving medical cases, it is essential to mainstream restorative justice in non-litigation approaches.

\section{Conclusion}

The application of restorative justice to medical dispute resolution in Indonesia deserves consideration based on several reasons and circumstances, such as the presence of relevant legal loopholes. Although not clearly and literally stated in various health law regulations, Article 29 of Law of the Republic of Indonesia Number 36/2009 concerning Health mentioned that medical disputes

52 Hendry Julian Noor and others, 'Application of Sanctions Against State Administrative Officials Failing to Implement Administrative Court Decisions', Bestuur, 9.1 (2021), 73-93.

53P. B. Murdi and W. T. N. Supanto, "The Role of Indonesian Honorary Council of Medical Discipline in Upholding Indonesian Medical Code of Ethics," Proceeding Adv. Soc. Sci. Educ. Humanit. Res. Atl. Press, vol. 358, 2019. See also P. B. Murdi, "The Application of the IPSA Loquitur Principle in the Regulation of Medical Malpractice Resolution'," Int. J. Innov. Creat. Chang., vol. 12, no. 12, pp. 756-764, 2020. Compare with E. Sutrisno and E. K. Dewi, "Dampak Putusan Mahkamah Agung Nomor 365 K/PID 2012 Terhadap Kinerja Dokter di Wilayah III Cirebon," J. Media Huk., vol. 23, no. 2, pp. 162-170, 2016. 
should be resolved by mediation. This shows that the legislators indeed want the dispute resolution process to use non-litigation approaches before leading to litigation.

Three pressing reasons exist for implementing restorative justice in medical dispute resolution. First, the need for mixed capabilities on medical and law science in the midst of law enforcement officers' competence is not well established. Second reason is the overcapacity condition of Indonesia's Correctional Institutions (Lapas) while imprisonment will only add to the congestion of prison. Third, the unbalanced ratio of Indonesia's health workers compare to the patients. The concept of criminalizing doctors is not an option because it may lead to fidgetiness for health workers themselves, as in the case of dr. Dewa Ayu Sasiary sparked mass action among doctors.

\section{Bibliography}

al-Ashfahani, Al-Rãghib, 'Al-Mufradãt Fĩ Gharĩb Al-Qur'e An' (Beirut: Beirut: Dar al-Ma’rifah),q’ p. 284

Al-Aynayni, Abu Muhammad Mahmud Ibn, 'Ahmad. Al-Bidãyah Fi Syarh Al-Hidãyah Vol-9' (Beirut: Dar al-Fikr, t. th), p. 3

Al-Qurtubi, Abu Abdullah Muhammad bin, and Ahmad bin Abu Bakr Al-Ansari, 'Al-Jami'li Ahkam Al-Qur'an' (Beirut: Muassasah al-Risalah, 2003), 323

Balch, Charles M., Michael R. Oreskovich, Lotte N. Dyrbye, Joseph M. Colaiano, Daniel V. Satele, Jeff A. Sloan, and others, 'Personal Consequences of Malpractice Lawsuits on American Surgeons', Journal of the American College of Surgeons, 213.5 (2011), 657-67 <https:/ / doi.org/10.1016/j.jamcollsurg.2011.08.005>

Cheluvappa, Rajkumar, and Selwyn Selvendran, 'Medical Negligence - Key Cases and Application of Legislation', Annals of Medicine and Surgery, 57 (2020), 205-11 <https:// doi.org/10.1016/j.amsu.2020.07.017>

Clamp, Kerry, Restorative Justice in Transition, Restorative Justice in Transition (Routledge, <https:// doi.org/10.4324/9780203715192> 2013)

Dartanto, Teguh, Wahyu Pramono, Alvin Ulido Lumbanraja, Chairina Hanum Siregar, Hamdan Bintara, Nia Kurnia Sholihah, and others, 'Enrolment of Informal Sector Workers in the National Health Insurance System in Indonesia: A Qualitative Study', 
Lego Karjoko, I Gusti Ayu Ketut Rachmi Handayani, Abdul Kadir Jaelani, Jaco Barkhuizen, Muhammad Jihadul Hayat

Heliyon, $\quad 6.11 \quad$ (2020), e05316 <https:// doi.org/10.1016/j.heliyon.2020.e05316>

Decker, Michele R., Charvonne N. Holliday, Zaynab Hameeduddin, Roma Shah, Janice Miller, Joyce Dantzler, and others, 'Defining Justice: Restorative and Retributive Justice Goals Among Intimate Partner Violence Survivors', Journal of Interpersonal Violence, 2020, 0886260520943728 <https:// doi.org/10.1177/0886260520943728>

Deri, Mulyadi, 'Penyelesaian Kasus Kelalaian Medik Melalui Litigasi Dan Non Litigasi Di Indonesia' (Padang: Universitas Andalas, 2019)

Díaz Crescitelli, Matías Eduardo, Mark Hayter, Giovanna Artioli, Leopoldo Sarli, and Luca Ghirotto, 'Relational Dynamics Involved in Therapeutic Discordance among Prescribers and Patients: A Grounded Theory Study', Patient Education and Counseling, 2021 <https:/ / doi.org/10.1016/j.pec.2021.05.041>

Dickens, B. M., 'Patients' Rights', in Encyclopedia of Applied Ethics, ed. by Ruth B T - Encyclopedia of Applied Ethics (Second Edition) Chadwick (San Diego: Academic Press, 2012), pp. 370-79 <https:/ / doi.org/10.1016/B978-0-12-373932-2.00160-5>

Flynn, M., 'Medical Malpractice - Medicolegal Perspectives: Negligence, Standard of Care', in Encyclopedia of Forensic and Legal Medicine: Second Edition, ed. by Jason Payne-James and Roger W B T - Encyclopedia of Forensic and Legal Medicine (Second Edition) Byard (Oxford: Elsevier, 2015), pp. 365-69 <https:// doi.org/10.1016/B978-0-12-800034-2.00284-6>

Grewal, Gagan, Teja Polisetty, Andrew Boltuch, and Jonathan C. Levy, 'Does Knowledge of Medical Risk Influence Patient Decision for Same Day Discharge Following Primary Shoulder Arthroplasty: A Randomized Control Trial', Seminars in Arthroplasty JSES, $31.2 \quad$ (2021), 353-59 <https://doi.org/10.1053/j.sart.2021.02.008>

Handayani, I.G.A.K. Rachmi, Lego Karjoko, and Abdul Kadir Jaelani, 'Model Pelaksanaan Putusan Mahkamah Konstitusi Yang Eksekutabilitas Dalam Pengujian Peraturan PerundangUndangan Di Indonesia', Bestuur, 7.1 (2019), 36-46 <https://jurnal.uns.ac.id/ bestuur/article/view/42700>

Hariyanto, Erie, Abd Hannan, Arif Wahyudi, Eka Susylawati, and Bhismoadi 
Tri Wahyu Faizal. "Sakinah Family Empowerment by Optimizing the Role of BP4 and Parents Mental Revolution Perspective." Samarah: Jurnal Hukum Keluarga Dan Hukum Islam 5, no. 2 (December 26, 2021): 619. https://doi.org/10.22373/sjhk.v5i2.10965.

Herlianto, S, 'Mediasi Penal Sebagai Alternatif Penyelesaian Perkara Malpraktik Kedokteran' (Semarang: Faculty of Law, Diponegoro University, 2015)

Hidayah, Nur Putri, Quincy R Cloet, and David Pradhan, 'The Implementation of Labor Development Principles According to Job Creation Law as a Reason to Protect Wages Rights', BESTUUR, 9.1 (2021), 94-105

Irfan, Mohammad, 'Mediation as A Choice of Medical Dispute Settlements in Positive Law of Indonesia', Sociological Jurisprudence Journal, 2.2 (2019), 116-21

Iswanty, Murji, Abdul Razak, Slamet Sampurno, and Hamzah Halim, 'Maladministration as Doctor Medical Malpractice: A Health Law Perspective in Indonesia', JL Pol'y E Globalization, 67 (2017), 167

Karjoko, Lego, Zaidah Nur Rosidah, and I Gusti Ayu Ketut Rahmi Handayani, 'Refleksi Paradigma Ilmu Pengetahuan Bagi Pembangunan Hukum Pengadaan Tanah', Bestuur, 7.2 (2020), 1 <https:// doi.org/10.20961/bestuur.v7i1.42694>

Kathir, Ibn, 'Tafsir Al-Quran Al Adhim Vol 2' (Beiru: Dar El-Fikr, 1999), p. 296

Kawalek, Anna, 'A Tool for Measuring Therapeutic Jurisprudence Values during Empirical Research', International Journal of Law $\begin{array}{llll}\text { and Psychiatry, } & 71 & \text { (2020), } & 101581\end{array}$ <https://doi.org/10.1016/j.ijlp.2020.101581>

Khodapanahandeh, Solmaz, and Siti Naaishah Hambali, 'Efficiency of Using " Alternative Dispute Resolution " Method in Medical Negligence Claims', Advances in Natural and Applied Sciences, 8.October (2014), 1-5

Kuo, Shih Ya, Dennis Longmire, and Steven J. Cuvelier, 'An Empirical Assessment of the Process of Restorative Justice', Journal of Criminal Justice, $38.3 \quad$ (2010), 318-28 <https:// doi.org/10.1016/j.jcrimjus.2010.03.006>

Laksono, Agung Dwi, Ilham Akhsanu Ridlo, and Ernawaty Ernawaty, 
Lego Karjoko, I Gusti Ayu Ketut Rachmi Handayani, Abdul Kadir Jaelani, Jaco Barkhuizen, Muhammad Jihadul Hayat

'Distribution Analysis of Doctors in Indonesia', Jurnal $\begin{array}{lllll}\text { Administrasi Kesehatan Indonesia, } 8.1 & \text { (2020), } & 29\end{array}$ <https:// doi.org/10.20473/jaki.v8i1.2020.29-39>

Li, Yuan, Dong Gao, Weibo Liang, Lirong Qiu, Xin Liu, Lin Zhang, and others, 'A Comparison of Malpractice Lawsuits Mediated and Judged in Court in China', Journal of Forensic and Legal Medicine, 54 (2018), 109-13 <https:// doi.org/10.1016/j.jflm.2018.01.002>

Lintang, Loresta Cahyaning, Adriano Martufi, and J W Ouwerker, 'The Alternative Concepts of Blasphemy Law in Indonesia: Legal Comparison with Ireland and Canada', BESTUUR, 9.1 (2021), 1733

Manzūr, Ibn, 'Lisãn Al-'arab, Vol. 3-4' (Mesir: al-Dãr al-Mishriyyah Lita"lĩf wa al-Tarjamah), p. 348

Meliala, Andreasta, Krishna Hort, and Laksono Trisnantoro, 'Addressing the Unequal Geographic Distribution of Specialist Doctors in Indonesia: The Role of the Private Sector and Effectiveness of Current Regulations', Social Science and Medicine, 82 (2013),

30-34 <https:// doi.org/10.1016/j.socscimed.2013.01.029>

Mulyadi, Deri, Elwi Danil, Wila Chandrawila, and Kurnia Warman, 'Medical Negligence Dispute Settlement in Indonesia', Indian Journal of Forensic Medicine and Toxicology, 14.4 (2020), 4229-33 <https:// doi.org/10.37506/ijfmt.v14i4.12304>

Van Ness, Daniel W., and Karen Heetderks Strong, '2 - A Brief History of Restorative Justice: The Development of a New Pattern of Thinking', in Restoring Justice, ed. by Daniel W Van Ness and Karen Heetderks B T - Restoring Justice (Fifth Edition) Strong (Boston: Anderson Publishing, Ltd., 2015), pp. 23-41 <https:// doi.org/https:/ / doi.org/10.1016/B978-1-4557-31398.00002-9>

Van Ness, Daniel W, and Karen Heetderks Strong, '3 - Restorative Justice: Justice That Promotes Healing BT - Restoring Justice (Fifth Edition)', ed. by Daniel W Van Ness and Karen Heetderks B T - Restoring Justice (Fifth Edition) Strong (Boston: Anderson Publishing, Ltd., 2015), pp. 43-60 $<$ https:// doi.org/https:// doi.org/10.1016/B978-1-4557-31398.00003-0> 
Noor, Hendry Julian, Kardiansyah Afkar, Henning Glaser, and Universitas Gadjah Mada, 'Application of Sanctions Against State Administrative Officials Failing to Implement Administrative Court Decisions', Bestuur, 9.1 (2021), 73-93

Novianto, Widodo Tresno, Alternatif Model Penyelesaian Sengketa Medik Di Luar Pengadilan Melalui Lembaga Penyelesaian Sengketa Medik Dalam Pelayanan Kesehatan (Surakarta: Sebelas Maret University Press, 2014)

Novikasari, Siti Rahma, Duc Quang Ly, and Kerry Gershaneck, 'Taxing Micro, Small and Medium Enterprises in Yogyakarta: Regulation and Compliance', Bestuur, 9.1 (2021)

Pakpahan, Kartina, $\mathrm{O} \mathrm{K}$ Isnainul, and Emir Syarif Fatahillah Pakpahan, 'Mediation As An Alternative For Medical Dispute Resolution Between Doctors And Patients In Approval Of Medical/Medical Actions', South East Asia Journal of Contemporary Business, Economics and Law, 24.3 (2021), 173-86

Presser, Lois, and Patricia Van Voorhis, 'Values and Evaluation: Assessing Processes and Outcomes of Restorative Justice Programs', Crime and Delinquency, 48.1 (2002), 162-88 <https:/ / doi.org/10.1177/0011128702048001007>

Putri, Wulandari Berliani, Vita Widyasari, Juliet Musabula, and Muhammad Jihadul Hayat, 'Medicolegal Perspective on Physician-Induced Demand Issue', BESTUUR, 9.1 (2021), 106-24

Rahardjo, Satjipto, Hukum Dan Perubahan Sosial Suatu Tinjauan Teoritis Serta Pengalaman-Pengalaman Di Indonesia, Yogyakarta: Genta Publishing (Genta Publishing, 2009)

Rosidah, Zaidah Nur, 'Coherence of the Rules of Sharia Against $\begin{array}{llll}\text { Pancasila', } \quad B e s t u u r, & 8.1 & \text { (2020), }\end{array}$ <https:// doi.org/10.20961/ bestuur.v8i1.42723>

Saidah Fasihah Binti Che Yussoff, and Rohaida Nordin, 'Freedom of Expression in Malaysia: Compatibility with the International Human Rights Standard Saidah', Bestuur, 9.1 (2021), 44-59

Shadily, Hassan, Ensiklopedi Indonesia (Jakarta: Ichtiar Baru-Van Hoeve, 1980)

Shewan, Garry, 'A Business Case for Restorative Justice', London: Restorative Justice Council. Http:/Www. Restorativejustice. Org. Uk/Resource/The_Business_case_for_restorative_justice_and_policing, 2010, 1-15 
Lego Karjoko, I Gusti Ayu Ketut Rachmi Handayani, Abdul Kadir Jaelani, Jaco Barkhuizen,

Muhammad Jihadul Hayat

Shurtz, Ity, 'The Impact of Medical Errors on Physician Behavior: Evidence from Malpractice Litigation', Journal of Health Economics, $\quad 32.2 \quad$ (2013), $331-40$ $<$ https:// doi.org/10.1016/j.jhealeco.2012.11.011>

Susila, Muh Endriyo, 'Implementing Dispute Resolution Mechanisms for RESOL Ving Medical Malpractice Cases in Indonesia: Problems and Prospects' (Kuala Lumpur: Ahmad Ibrahim Kulliyyah of Law, International Islamic ..., 2020)

Syaufi, Ahmad, Diana Haiti, and Mursidah, 'Application of Restorative Justice Values in Settling Medical Malpractice Cases', International Journal of Criminology and Sociology, 10.7 (2021), 103$10<$ https://doi.org/10.6000/1929-4409.2021.10.14>

Tamanaha, Brian Z., 'Legal Positivism', in International Encyclopedia of the Social \& Behavioral Sciences: Second Edition, ed. by James D B T - International Encyclopedia of the Social \& Behavioral Sciences (Second Edition) Wright (Oxford: Elsevier, 2015), pp. 762-66 <https:/ / doi.org/10.1016/B978-0-08-097086-8.86074-2>

Triwanto, Triwanto, and Esti Aryani, 'The Urgency of Granting Authority to Assess Corruption Justice Collaborators', Bestuur, 8.1 (2020), 60 <https:// doi.org/10.20961/bestuur.v8i1.42720>

Voll, John O, 'Renewal and Reform in Islamic History: Tajdid and Islah', in Voices of Resurgent Islam, ed. by John L. Esposito (New York: Oxford University Press New York, 1983), pp. 32-47

Yuniza, Mailinda Eka, 'Arah Kebijakan Pengaturan Bidang Kesehatan Pada Era Otonomi Luas' (Yogyakarta: Universitas Gadjah Mada, 2016)

Yusriando, Yusriando, 'Konstruksi Sistem Jaminan Sosial Nasional Bidang Kesehatan', Bestuur, 7.2 (2019), 122 <https:// doi.org/10.20961/ bestuur.v7i2.41538> 